\title{
Preparation of Translucent and Flexible Human Hair Protein Films and Their Properties
}

\author{
Toshihiro FuJI* and Yusuke IDE \\ Faculty of Textile Science and Technology, Shinshu University; 3-15-1 Tokida, Ueda, Nagano 386-8567, Japan. \\ Received February 23, 2004; accepted June 7, 2004
}

\begin{abstract}
We have developed novel procedures for preparing human hair protein films (Pre-cast and Post-cast methods). The light brown films obtained by these procedures were too fragile to apply to human skin. We found that the film was also formed when the hair proteins extracted by the Shindai method were directly exposed to the solution containing $\mathrm{MgCl}_{2}, \mathrm{CaCl}_{2}, \mathrm{NaCl}$ or $\mathrm{KCl}$. Scanning electron microscopy (SEM) and atomic force microscopy (AFM) showed that the surface of the novel protein films was smooth. The protein films mainly consist of $\alpha$-keratins and matrix proteins. After drying, the films became translucent and flexible during folding, indicating the possibility that these protein films are useful for practical applications. Hence, we prepared gauze-coated protein films to reinforce their physical strength and tested the influence on human skin. A patch test showed that the protein films made from individual and multiple human hairs only slightly stimulated rubor and anthema, itching, drying, smarting and pain on the contact area of arm skin.
\end{abstract}

Key words human hair protein film preparation; keratin; matrix protein; skin patch test

Bio-films have been used in medical wound dressings, ${ }^{1)}$ the immobilization of biopolymers and bioactive substances, ${ }^{2-4)}$ the improvement of enzyme stability, ${ }^{4-6)}$ and drug-delivery systems. ${ }^{7)}$ Various proteins including human hair and wool keratin, ${ }^{8-10)}$ collagen, ${ }^{7)}$ fibrin, ${ }^{11)}$ silk fibroin ${ }^{12)}$ and their mixtures ${ }^{13,14)}$ have been utilized as the starting materials of protein films. The protein film formation is due to the properties of these proteins such as self-assembly, selfaggregation, polyacid-polybase interaction and cross-linking activities.

During the course of our continuing study on the application of human hair and wool proteins, we first developed a rapid and convenient procedure of protein isolation from biomaterials containing hard $\alpha$-keratin, called the "Shindai Method." ${ }^{15,16)}$ Most recently, we reported novel preparation procedures for protein film from human hair proteins dissolved in the Shindai solution and called the "Pre-cast and Post-cast methods." ${ }^{3,8,9)}$ The hair protein film with a $10 \mathrm{~cm}^{2}$ area and $10-20 \mu \mathrm{m}$ thickness was prepared from $10 \mathrm{mg}$ of hair protein by the Post-cast method $(100 \mathrm{~mm}$ acetate buffer, $\mathrm{pH}$ 4). This was extracted from $20 \mathrm{mg}$ of original hair biosynthesized on our heads within $2 \mathrm{~h}$ in vivo. The human hair protein film was digested by trypsin, chymotrypsin, proteinase $\mathrm{K}$ and pronase $\mathrm{E}$ and slightly by $\mathrm{V} 8$ protease and papain in vitro. ${ }^{9)}$ The difference in the susceptibility among these proteolytic enzymes was explained by the specificity toward the peptide bound to be cleaved. Furthermore, alkaline phosphatase was incorporated into the protein film without significant chemical modification. ${ }^{3)}$ However, the protein films have poor strength and flexibility. These physical properties prevent their application as medical and cosmetic biomaterials.

In the present study, we report an improved procedure for preparing human hair protein film with translucent and flexible properties and called it the soft Post-cast method. Hair protein film reinforced by cloth was also prepared. Protein film prepared from the hair of 6 volunteers was placed under their own arms for $5 \mathrm{~d}$. This procedure was found to have little impact on the visual and sensory evaluations carried out by them.

\section{MATERIALS AND METHODS}

Extraction of Protein Solution from Human Hair and Preparation of Protein Films The human hair protein solution was prepared as previously described. ${ }^{15,16)}$ Briefly, human hair after washing with ethanol was incubated with Shindai solution consisting of $25 \mathrm{~mm}$ Tris- $\mathrm{HCl}$, pH 8.5, 2.6 M thiourea, $5 \mathrm{M}$ urea and 5\% 2-mercaptoethanol (2-ME) at $50^{\circ} \mathrm{C}$ for $2-4 \mathrm{~d}$. After filtration, the solution was further centrifuged at $15000 \mathrm{~g}$ for $10 \mathrm{~min}$ at $25^{\circ} \mathrm{C}$ and the supernatant was used as the starting protein solution for the protein films.

The hair protein solution $(5.4 \mathrm{mg} / \mathrm{ml}, 200 \mu \mathrm{l})$ was directly exposed in tissue cultured dishes $(\phi 35 \times 10 \mathrm{~mm})$ containing $5 \mathrm{ml}$ of $0-40 \mathrm{~mm} \mathrm{MgCl}_{2}, 0-40 \mathrm{~mm} \mathrm{CaCl}_{2}, 0-450 \mathrm{~mm}$ $\mathrm{NaCl}$ or $0-450 \mathrm{~mm} \mathrm{KCl}$. After standing for $1-2 \mathrm{~h}$ at room temperature, a membrane-like protein aggregate was formed and washed by rinsing with water for over $12 \mathrm{~h}$ and then replaced with distilled water for $3 \mathrm{~h}$. The films were thoroughly dried in a silicagel box and the protein recovery as the film was calculated by weighing using an electronic balance. The protein concentrations were determined according to Bradford ${ }^{17)}$ using bovine serum albumin as the standard.

Electrophoresis Sodium dodecyl sulfate-polyacrylamide gel electrophoresis (SDS-PAGE) was performed according to the method of Laemmli ${ }^{18)}$ using a $13.5 \%$ slab gel. Proteins in the gel were stained with $0.1 \%$ Coomassie brilliant blue R$250,10 \%$ acetic acid and $40 \%$ ethanol for $1-3 \mathrm{~h}$ and destained in 10\% acetic acid and $40 \%$ ethanol.

Scanning Electron Microscopy (SEM) and Atomic Force Microscopy (AFM) The SEM observations were carried out following the previously described conventional method. ${ }^{3,8}$ Protein films were splattered with gold and examined with a S2380N scanning electron microscope (Hitachi). The AFM image was obtained using a scanning probe microscope (Shimadzu SPM-9500JB) operating in the constant force regime. The images were obtained over a $20 \mu \mathrm{m} \times$ 
$20 \mu \mathrm{m}$ area at a scanning rate of $1 \mathrm{~Hz}$.

Evaluation of Skin Administered with Hair Protein Films The patch test was carried out using volunteers on the inner aspect of the forearm with gauze-coated protein films $(\phi 30 \mathrm{~mm})$ prepared from their own or other multiple persons' hair and control gauze. These films and gauze were attached to the arms with an elastic bandage (Nichiban) for $5 \mathrm{~d}(8 \mathrm{~h} / \mathrm{d})$. After removing the films and gauze, evaluation and observation of the changes in their skin were performed daily over this period. The reactions were considered negative $(-)$, doubtful (?) or positive $(+)$.

\section{RESULTS AND DISCUSSION}

Preparation of Flexible Hair Protein Films by Soft Post-Cast Methods We have recently developed two novel procedures for preparing hair protein films using a protein solution consisting of hard $\alpha$-keratins and matrix proteins obtained by the Shindai method. ${ }^{3,8,15)}$ The protein solution in the first denaturant $(25 \mathrm{~mm}$ Tris- $\mathrm{HCl}, \mathrm{pH} 8.5,2.6 \mathrm{~m}$ thiourea, $5 \mathrm{~m}$ urea and 5\% 2-mercaptoethanol) was mixed with the second denaturants such as trichloroacetic acid (TCA), perchloric acid (PCA), or guanidine- $\mathrm{HCl}$ (GHA), and then cast in distilled water (Pre-cast method). Water-insoluble protein films were formed. Next, the protein was directly cast in the second denaturant solutions containing TCA, PCA, GHA, $\mathrm{HCl}, \mathrm{H}_{2} \mathrm{SO}_{4}$ or acetate buffer (hard Post-cast method). Films with a light brown color were immediately formed. In both cases, the maximum protein recovery in the films was 60 $85 \%$ and the protein component mainly consisted of $\alpha$-keratin. All films were too fragile for use as an artificial skin or a cosmetic pack.

In the Post-cast method, we found that film-like protein aggregates were also formed when the hair protein solution prepared by the Shindai Method was directly exposed to the solution containing $\mathrm{MgCl}_{2}, \mathrm{CaCl}_{2}, \mathrm{NaCl}$ or $\mathrm{KCl}$, in addition to the second denaturant. Figure 1 shows the concentration dependence of these reagents on the amount of protein recovered as film-like aggregates. When $\mathrm{MgCl}_{2}$ and $\mathrm{CaCl}_{2}$ were used as the developing solvents of the Post-cast method, protein films were formed over $10 \mathrm{~mm} \mathrm{MgCl}_{2}$ or $\mathrm{CaCl}_{2}$ and the maximum yield was approximately $70-80 \%$ (Fig. 1A). On the other hand, when $\mathrm{NaCl}$ and $\mathrm{KCl}$ were used as the developing solvents, film formation was observed at higher concentrations of the solvents (around $250 \mathrm{~mm}$ ) and the maximum yield was greater than $50-60 \%$ (Fig. 1B). The addition of $\mathrm{NaCl}$ or $\mathrm{KCl}$ to the $\mathrm{MgCl}_{2}$ solvent did not affect the concentration dependence of the film formation (data not shown). Similar results were obtained when $\mathrm{Mg}\left(\mathrm{CH}_{3} \mathrm{COO}\right)_{2}$ and $\mathrm{Mg}\left(\mathrm{NO}_{3}\right)_{2}$ were used instead of $\mathrm{MgCl}_{2}$, indicating that divalent cations such as $\mathrm{Mg}^{2+}$ or $\mathrm{Ca}^{2+}$ are essential for protein film formation. Compared to the films obtained by both the Pre- and Post-cast methods, ${ }^{3,8,9)}$ the films obtained by the soft Post-cast method were more flexible. The durability of the films stuck on clear-plastic wrap was demonstrated by folding and unfolding them more than twenty times without any significant damage. These protein films by the soft Postcast methods $\left(\mathrm{MgCl}_{2}, \mathrm{CaCl}_{2}, \mathrm{NaCl}\right.$ or $\left.\mathrm{KCl}\right)$ were clear enough to show the letters on the paper after drying (Fig. 1C), whereas the films made by hard Post-cast method (acetate buffer) were light brown and slightly pellucid.

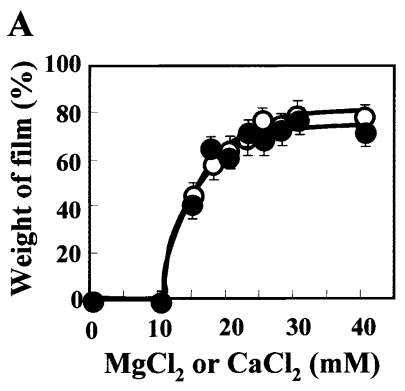

C (a)

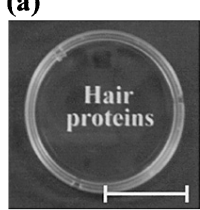

(d)

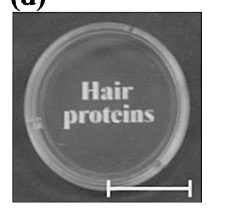

(b)

(e)
B
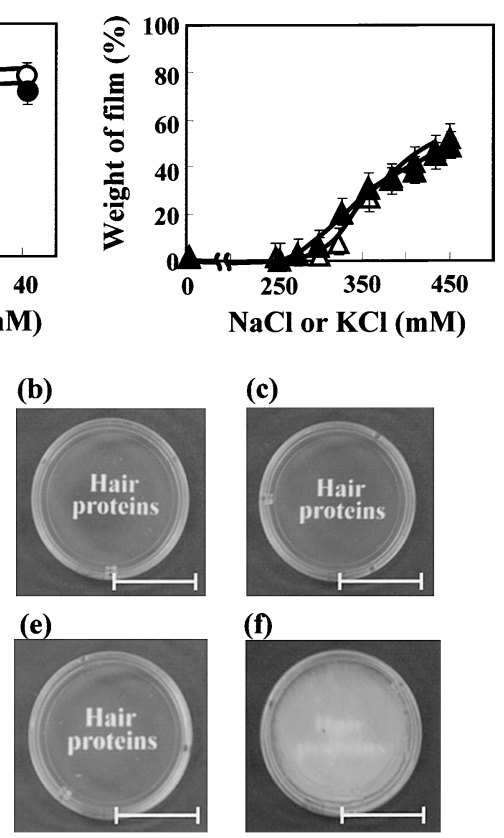

(c)

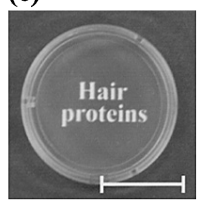

(f)

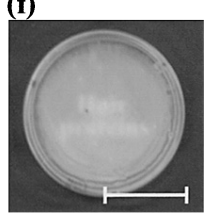

Fig. 1. Effects of $\mathrm{MgCl}_{2}, \mathrm{CaCl}_{2}, \mathrm{NaCl}$ or $\mathrm{KCl}$ on the Recovery of Human Hair Protein Films

(A, B) Human hair protein solution $(5.4 \mathrm{mg}$ ) dissolved in $25 \mathrm{~mm}$ Tris- $\mathrm{HCl}, \mathrm{pH} 8.5$, $2.6 \mathrm{M}$ thiourea, $5 \mathrm{~m}$ urea and $5 \% 2-\mathrm{ME}$ was directly exposed to various concentrations of $\mathrm{MgCl}_{2}(\bullet), \mathrm{CaCl}_{2}(\bigcirc), \mathrm{NaCl}(\boldsymbol{\Delta})$ and $\mathrm{KCl}(\triangle)$ as indicated. After storing for $1-2 \mathrm{~h}$ and washing the resulting protein aggregates, the quantities of protein recovered as the films were calculated by weighing. Each value represents the mean \pm S.D. $(n=3)$. (C) Films of Post-cast method; (a), tissue cultured dishes; (b), $15 \mathrm{~mm} \mathrm{MgCl}_{2} ;$ (c), $15 \mathrm{~mm}$ $\mathrm{CaCl}_{2}$; (d), $450 \mathrm{~mm} \mathrm{NaCl}$; (e), $450 \mathrm{~mm} \mathrm{KCl}$; (f), $100 \mathrm{~mm}$ acetate buffer, $\mathrm{pH} 4$. Bars, $1 \mathrm{~cm}$.

Visualization of Film Surface by Scanning Electron Microscopy and AFM When protein films were prepared by the Pre-cast and hard Post-cast methods (TCA, PCA, GHA and acetate buffer), ${ }^{3,8,9)}$ the fine structure of the films exhibited a heterogenous surface composed of filamentous structures, particles with a diameter of $1-2 \mu \mathrm{m}$, and connecting structure among the filaments and particles. On the other hand, these structures were not observed in the flexible films. The surface of the films appeared to be flat in the SEM observations (Fig. 2A). The smooth structure of the flexible films was confirmed by AFM (Fig. 2B). The unevenness of the lateral surface of the flexible films $\left(\mathrm{MgCl}_{2}\right.$ and $\left.\mathrm{NaCl}\right)$ was less than $2 \mu \mathrm{m}$, whereas the value of the film (100 mm acetate buffer, $\mathrm{pH} 4.5)$ was $5-6 \mu \mathrm{m}$. These results suggest that the film formation mechanism is different in the two methods.

Protein Composition of the Flexible Hair Protein Film These protein films prepared by the soft Post-cast method $\left(\mathrm{MgCl}_{2}, \mathrm{CaCl}_{2}, \mathrm{NaCl}\right.$ and $\left.\mathrm{KCl}\right)$ were stored for 4 weeks in the dry state at room temperature. They were then re-extracted using the Shindai solution for $2 \mathrm{~d}$ at $50^{\circ} \mathrm{C}$, and the protein compositions were then analyzed by SDS-PAGE (Fig. $3)$. The extracted solution of all the films mainly consisted of $\alpha$-keratins with molecular masses of $40-60 \mathrm{kDa}$ and matrix proteins of $10-30 \mathrm{kDa}$. Significant protein hydrolysis was not found during the film formation nor during the storage period. Interestingly, the contents of the matrix proteins which are known as keratin-associated proteins in the flexible films are more than those of the films prepared by the hard Post-cast method. The flexible property and smooth surface 
A

(a)

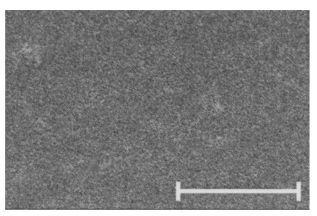

(c)

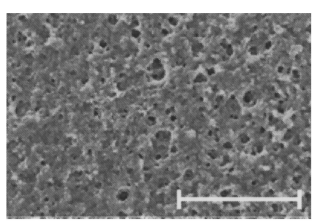

B

(d)

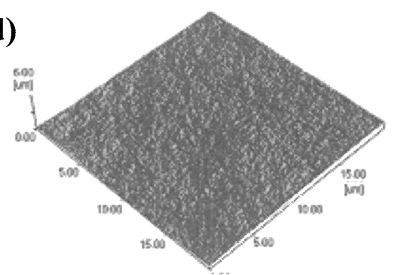

(f)

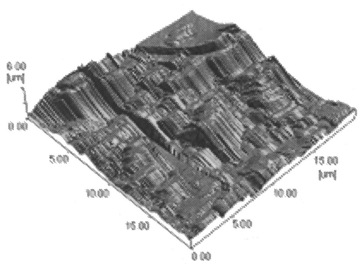

(b)

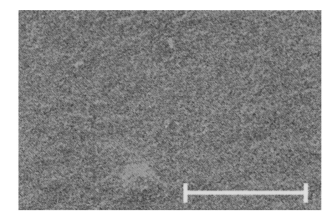

A

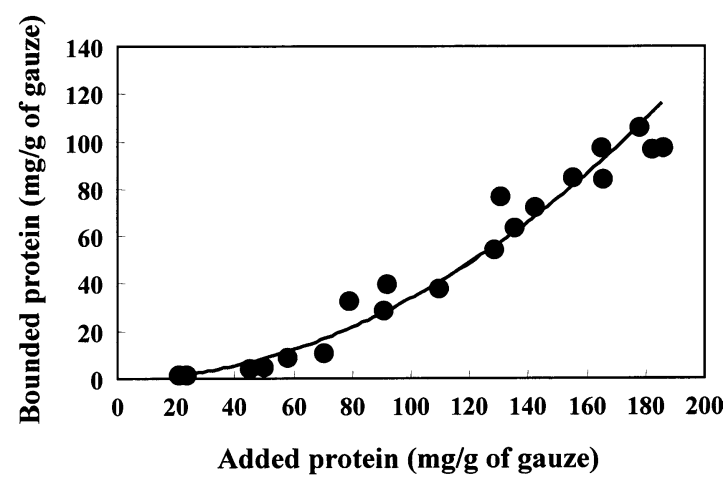

B

(a)
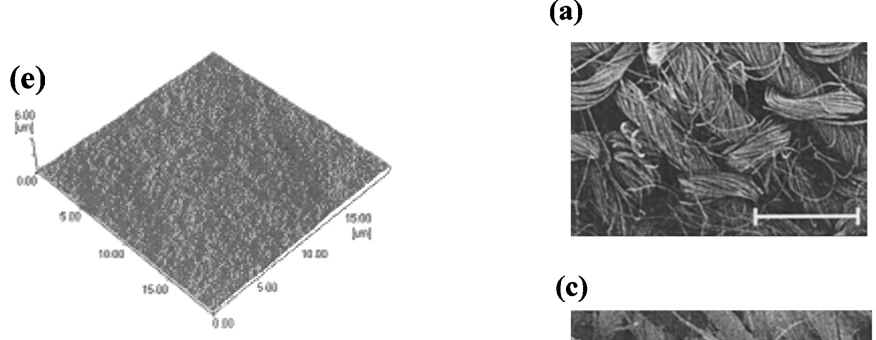

(b)

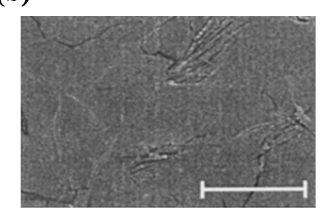

(c)

Fig. 2. Morphological Observation of Hair Protein Films

Hair protein films were observed by SEM (A) and AFM (B). AFM shows a composite $3 \mathrm{D}$ image of the surface characteristics of the hair protein films. a and d, soft Postcast method (40 mM $\left.\mathrm{MgCl}_{2}\right)$; b and e, soft Post-cast method $(1 \mathrm{M} \mathrm{NaCl})$; $\mathrm{c}$ and $\mathrm{f}$, hard Post-cast method (100 mm acetate buffer, $\mathrm{pH} 4)$. Bars in A, $50 \mu \mathrm{m}$.

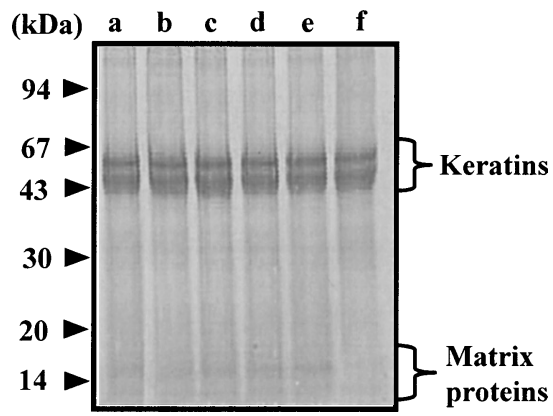

Fig. 3. SDS-PAGE of the Extracted Protein from Hair Protein Films

Hair protein films prepared by the Post-cast method were incubated with $25 \mathrm{~mm}$ Tris- $\mathrm{HCl}, \mathrm{pH} 8.5,2.6 \mathrm{M}$ thiourea, $5 \mathrm{M}$ urea and $5 \% 2-\mathrm{ME}$ at $50{ }^{\circ} \mathrm{C}$ for $2 \mathrm{~d}$. Extracted proteins were analyzed by $13.5 \%$ SDS-PAGE. a, Original human hair protein; $b, 15 \mathrm{~mm}$ $\mathrm{MgCl}_{2} ; \mathrm{c}, 15 \mathrm{~mm} \mathrm{CaCl}$; d, $450 \mathrm{~mm} \mathrm{NaCl} ; \mathrm{e}, 450 \mathrm{~mm} \mathrm{KCl} ;$ f, $100 \mathrm{~mm}$ acetate buffer (pH 4).

of the films may be due to the higher matrix protein content. We used the protein films prepared in $\mathrm{MgCl}_{2}$ solution in the following experiments.

Preparation of the Hair Protein Film Reinforced with Cotton Gauze The hair protein films prepared by the soft Post-cast method were still weak for practical use. Consequently, cotton gauze was added to the incubation mixture to

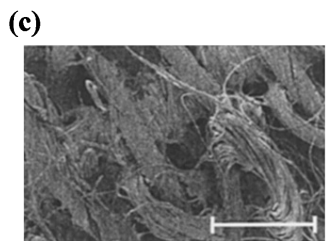

Fig. 4. Protein Recovery in Gauze-Coated Film and Morphological Observation

(A) Human hair protein solution dissolved in $25 \mathrm{~mm}$ Tris- $\mathrm{HCl}, \mathrm{pH} 8.5,2.6 \mathrm{~m}$ thiourea, $5 \mathrm{~m}$ urea and 5\% 2-ME was directly exposed to weighed gauze immersed in $40 \mathrm{mM} \mathrm{MgCl} 2$ solution. The gauze-coated protein films were obtained after setting for $2 \mathrm{~h}$ and washing with flowing distilled water. Proteins contained in the films were re-extracted by the Shindai solution and the quantities were determined by the method of Bradford. ${ }^{17)}$ (B) Photographs of the surface of hair protein films reinforced by cotton gauze. a, cotton gauze only; b, contacted face to cultured dish; $c$, the other side of the film (b). Bars, $1 \mathrm{~mm}$.

increase the physical strength of the protein film. When the hair protein solution was exposed in tissue cultured dishes temporarily covered with the gauze, the amount of protein recovered in the gauze progressively increased with the increasing concentration of the added hair proteins (Fig. 4A). Interestingly, one surface of the gauze-coated films which was in contact with the cultured dish was smooth and consisted only of hair proteins over $80-90 \mathrm{mg}$ protein $/ \mathrm{g}$ of added cotton gauze (Fig. 4B). On the other hand, the other side was proteins plus cotton fibers. The flexible hair protein films reinforced with cotton gauze made it possible to test them on human skin.

\section{Skin Test of Hair Protein Films Reinforced with Cotton}

Gauze We prepared two kinds of gauze-coated protein films. One was prepared from the protein solution of the volunteers' own hairs and the other was derived from a mixture of multiple human hair. The resulting film at $130 \mathrm{mg}$ protein/g of cotton gauze seemed to be sufficient for practical use. The gauze-coated protein films were attached to the assigned site on the inner aspect of the forearm of 6 volunteers who did not have allergic tendencies. The application was done for $40 \mathrm{~h}(8 \mathrm{~h} \times 5 \mathrm{~d})$. Since there was no apparent breakage of the gauze-coated films after $5 \mathrm{~d}$ of use, the films appear to be capable of longer use. The skin changes (rubor and 
Table 1. Skin Patch Test with Gauze-Coated Protein Films

\begin{tabular}{|c|c|c|c|c|c|c|c|}
\hline & \multirow{2}{*}{ Reaction } & \multicolumn{2}{|c|}{ Appearance } & \multicolumn{4}{|c|}{ Sensitivity } \\
\hline & & Rubor & Anthema & Itch & Dry & Smart & Pain \\
\hline \multirow[t]{3}{*}{ Gauze only } & $-^{a)}$ & $6 / 6^{d)}$ & $6 / 6$ & $6 / 6$ & $6 / 6$ & $6 / 6$ & $6 / 6$ \\
\hline & $?^{b)}$ & $0 / 6$ & $0 / 6$ & $0 / 6$ & $0 / 6$ & $0 / 6$ & $0 / 6$ \\
\hline & $+^{c)}$ & $0 / 6$ & $0 / 6$ & $0 / 6$ & $0 / 6$ & $0 / 6$ & $0 / 6$ \\
\hline \multirow{3}{*}{$\begin{array}{l}\text { Gauze-coated protein films } \\
\text { (My hair proteins) }\end{array}$} & - & $6 / 6$ & $6 / 6$ & $6 / 6$ & $6 / 6$ & $6 / 6$ & $6 / 6$ \\
\hline & $?$ & $0 / 6$ & $0 / 6$ & $0 / 6$ & $0 / 6$ & $0 / 6$ & $0 / 6$ \\
\hline & + & $0 / 6$ & $0 / 6$ & $0 / 6$ & $0 / 6$ & $0 / 6$ & $0 / 6$ \\
\hline \multirow{3}{*}{$\begin{array}{l}\text { Gauze-coated protein films } \\
\text { (Other hairs proteins) }\end{array}$} & - & $6 / 6$ & $6 / 6$ & $6 / 6$ & $6 / 6$ & $6 / 6$ & $6 / 6$ \\
\hline & $?$ & $0 / 6$ & $0 / 6$ & $0 / 6$ & $0 / 6$ & $0 / 6$ & $0 / 6$ \\
\hline & + & $0 / 6$ & $0 / 6$ & $0 / 6$ & $0 / 6$ & $0 / 6$ & $0 / 6$ \\
\hline
\end{tabular}

The adverse reactions of the films on human skin were examined. The protein aspect of the films and control gauze were attached to the skin of the inner forearm for $5 \mathrm{~d}$ $(8 \mathrm{~h} / \mathrm{d}) . a)$ The reaction was negative. b) The reaction was doubtful. c) The reaction was positive. $d$ ) Subjects were 6 persons (men).

anthema) and sensory evaluations (itch, dry, smart and pain) were estimated every day. For the period, no significant changes such as adverse reactions were observed in any of the volunteers (Table 1).

We have prepared flexible hair protein films using the Post-cast method with slight modifications (soft Post-cast method). The physical properties (flexibility, transparency, and surface structure) of the protein films were quite different from those from the Pre-cast and hard Post-cast methods that we recently reported. ${ }^{3,8,9)}$ These characteristics may be due to the different assembly mechanisms to form the filmlike aggregates that are now under investigation. The high protein recovery $(70-80 \%)$ as films and the convenient procedure were adequate for practical use, for example, gauze-coated films with a $30 \mathrm{~mm}$ diameter and $0.5-0.6 \mathrm{~mm}$ in thickness used in Table 1 contained $15 \mathrm{mg}$ of hair protein which we can usually be synthesized within $3-4 \mathrm{~h}$ on the head in vivo. We are now investigating the physiological functions of these films such as anti-bacterial activity, antimold activity, and adhesion activity to cultured skin cells for use as wound dressings and cosmetic films.

Acknowledgments We wish to thank to Mike Honywood for his critical reading of the manuscript. This study was supported by Grants-in-Aids for COE Research (H10CE2003) and Science Research (B) (16350123) and (C) (14593003) from the Ministry of Education, Culture, Sports, Science and Technology of Japan.

\section{REFERENCES}

1) Sugihara A., Sugiura K., Morita H., Ninagawa T., Tobouchi K., Tobe R., Izumiya M., Horio T., Abraham N. G., Ikehara S., Proc. Soc. Exp. Biol. Med., 225, 58-64 (2000).

2) Mizuno K., Yamamura K., Yano K., Osada T., Saeki S., Takimoto N., Sakurai T., Nimura Y., J. Biomed. Mater. Res., 64A, 177-181 (2003).

3) Fujii T., Ogiwara D., Arimoto M., Biol. Pharm. Bull., 27, 89-93 (2004).

4) Lvov Y. M., Sukhorukov G. B., Membr. Cell Biol., 11, 277-303 (1997).

5) Tiller J. C., Rieseler R., Berlin P., Klemm D., Biomacromolecules, 3 $1021-1029$ (2002).

6) Amorim R. V. S., Melo E. S., Carneiro-da-Cunha M. G., Ledingham W. M., Campos-Takaki G. M., Bioresource Technol., 89, 35-39 (2003).

7) Lee C. H., Singla A., Lee Y., Int. J. Pharm., 221, 1-22 (2001).

8) Fujii T., Bio. Industry, 19, 22-27 (2002).

9) Ide Y., Fujii T., Kobunshi Ronbunshu, 61, 153-156 (2004).

10) Yamauchi K., Yamauchi A., Kusunoki T., Khoda A., Konishi Y., J. Biomed. Mater. Res., 31, 439-440 (1996).

11) Skarja G. A., Brash J. L., Bishop P., Woodhouse K. A., Biomaterials, 19, 2129-2138 (1998).

12) Um I. C., Kweon H. Y., Park Y. H., Hudson S., Int. J. Biol. Macromol., 29, 91-97 (2001).

13) Tanabe T., Okitsu N., Tachibana A., Yamauchi K., Biomaterials, 23, $817-825$ (2002).

14) Lee K. Y., Kong S. J., Park W. H., Ha W. S., Kwon I. C., J. Biomater. Sci. Polym. Ed., 9, 905-914 (1998).

15) Nakamura A., Arimoto M., Takeuchi K., Fujii T., Biol. Pharm. Bull., 25, 569-572 (2002).

16) Fujii T., Ikezoe N., Kobunshi Ronbunshu, 60, 354-358 (2003).

17) Bradford M. M., Anal. Biochem., 72, 248-254 (1976).

18) Laemmli U. K., Nature (London), 227, 680-685 (1970). 